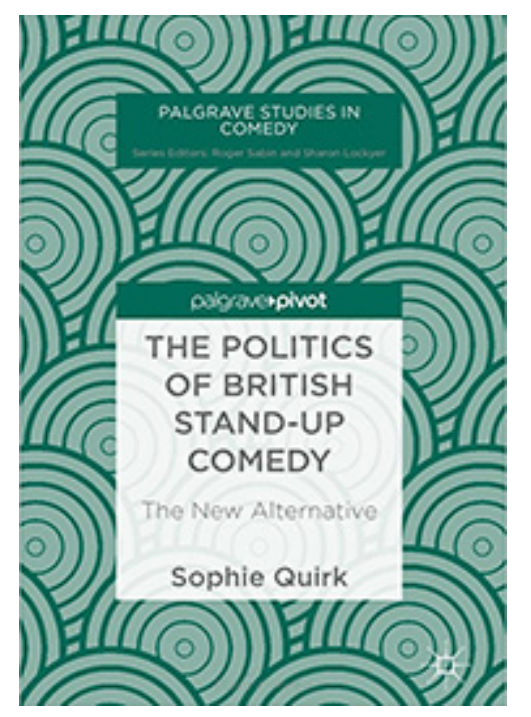

\section{VAIHTOEHTOKOMIIKAN MYÖHEMPIÄ VAIHEITA}

Sophie Quirk (2018): The Politics of British Stand-up Comedy: The New Alternative. Palgrave Studies in Comedy. Basingstoke: Palgrave Macmillan, $131 \mathrm{~s}$.
Sophie Quirk (Kentin yliopisto) on kasvavan stand up -tutkimuksen brittiläisiä asiantuntijoita, jonka väitöskirja koski Mark Thomasin poliittista komiikkaa ja edellinen teos Why stand-up matters: How comedians manipulate and influence (2015, Bloomsbury) stand up -komiikan valtadynamiikkaa. Uusimmassa kirjassaan hän syventyy brittiläisen "vaihtoehtoisen" stand up -komiikan (alternative comedy) genealogiaan, historiallisiin jatkuvuuksiin ja nykypäivän erityispiirteisiin. Vaikka tyylilajin kulta-ajaksi määritellään vuodet 1979-1990, sen vaikutus näkyy yhä tämän päivän stand upissa, komiikkadiskursseissa ja koomikoiden (itse)identifikaatioissa. Tällaisten yhtymäkohtien ja niiden vaihtuvien sosiaalisten ja poliittisten kontekstien perkaaminen on lyhyesti sanoen Quirkin kirjan ytimessä.

Vaihtoehtoinen tai "kokeellinen" stand up oli alkuaikoinaan 1970-luvun lopulla reaktiota hallitseville brittikomiikan perinteille: pohjoisen "työläiskomiikan" matalaotsaiselle seksismille, rasismille ja homofobialle, mutta toisaalta myös muodollisen älyllisiksi koetuille "Oxbridgen satiirikoille" eli Oxfordin ja Cambridgen eliittiyliopistotaustasta nouseville koomikoille. Jälkiviisaasta nykyperspektiivistä voi todeta, että vaihtoehtokoomikot olivat monissa teemoissaan edellä aikaansa. He olivat julkisista puhujista varhaisimpia, jotka esittelivät keskeisenä aseenaan nimenomaan poliittisen korrektiuden. Heidän pyrkimyksensä olivat aikanaan radikaaleja: he kieltäytyivät turvautumasta väsyneimpään "se oli vain vitsiä"-siilipuolustukseen ja toivat eksplisiit- tisesti esiin pyrkimyksensä puolustaa tasavertaisuutta "lyömällä ylöspäin" (punch up) kohti valtaapitäviä tai kulloinkin hallitsevia tahoja ja diskursseja. Nämä koomikot olivat vasemmistolaisesti identifioituvia boheemeja, taiteilijoita ja anarkisteja, jotka olivat ottaneet päämääräkseen yhteiskunnallisen muutoksen kokeellisen stand up -komiikan keinoin. Kapitalistisen ironian mukaisesti vaihtoehtokomiikasta tuli kuitenkin - totta kai - itse hegemoninen malli ja esikuva myöhemmälle brittiläiselle stand upille.

Vaihtoehtoisuutta voisikin stand upin yhteydessä jäsentää mielestäni muodon, sisällön ja funktion kannalta. Ensiksi, muodon osalta vaihtoehtokomiikka assosioituu ennen muuta kokeellisuuteen ja perinteisillä, kiteytyneillä stand up -juttujen kaavoilla leikittelemiseen. Toiseksi, sisällön osalta vaihtoehtokoomikot välttelevät perinteisimpiä rasistisia, seksistisiä, homofobisia ja muita xenofobisia teemoja. Ja kolmanneksi, funktion osalta he kieltävät, että kaiken komiikan tulisi välttämättä tähdätä (vain) naurattamiseen, ja etsivät sille muita merkityksiä ja tehtäviä.

\section{Vaihtoehtojen premissit}

Quirk hahmottelee tutkimuksensa metodologiaa väljän narratiivisen kehyksen kautta. Hänen historiantutkimuksellinen orientaationsa koskee etupäässä sitä, miten vaihtoehtokomiikan tarinaa on kerrottu ja miten se jäsentää komiikan kenttää ja yhteisöjä nykypäivänä. 
Lähestymistapa paljastaa vaihtoehtokomiikasta historiallisten kehityskulkujen ja vaikutussuhteiden sijaan pikemminkin sen hallitsevia diskursiivisia tendenssejä ja artikulaatioita, mitä voisi kutsua kulttuurintutkimukselliseksi näkökulmaksi (historialliseen) tutkimuskohteeseen. Näitä tendenssejä ja artikulaatioita, joiden pohjalle Quirk teoksensa rakentaa, ovat vasemmisto-oikeisto-akseli, poliittinen korrektius (eli kieli-ideologia), uusliberalismin vastustus, maun ja luokan artikulaatiot sekä poliittisen todellisuuden viimeaikaiset muutokset ja niin sanottu postanarkismi.

Johdatus vaihtoehtokomiikkaan alkaa hieman yllättäen pohdinnalla sen vastinparin eli konservatiivis-oikeistolaisen stand up -komiikan kriteereistä ja elinehdoista. Aiheen taustalla on brittilehdistössä joitain vuosia sitten käyty keskustelu siitä, onko oikeistolainen stand up oikea sosiokulttuurinen ilmiö - onko sellaista edes olemassa taide- ja komediakentällä, joka tavanomaisesti mielletään liberaalin vasemmiston hallitsemaksi? Koska kysymystä ei voi esittää ilman täsmennyksiä "poliittisuuden" kriteereistä ja lajin muodosta - koskien esimerkiksi jakoa koomikon henkilökohtaisen elämän ja hänen materiaalinsa välillä - se avaa erityisen hyvin erilaisia komediaa koskevia ideologisia taustaoletuksiamme, jotka liittyvät esimerkiksi yhteiskunnallisesti kantaa ottavan satiirin luontaiseen "edistyksellisyyteen" tai vasemmistolaisuuteen. Satiirin ajatellaan "lyövän ylöspäin" kohti auktoriteetteja ja normatiivista sosiaalista järjestystä, aivan kuin komedian ajatellaan olevan pienen ihmisen puolella - tai kuten komediaohjaaja-käsikirjoittaja Atte Järvinen esittää, "komiikka ei voi perustua epäreilulle havainnolle" ja tuppaa näin ollen olemaan humanistista (ks. Lindström 2017). Vastaavien näkemysten ongelma on siinä, että altavastaajan asemaa voidaan retorisesti soveltaa hyvin monenlaisten asioiden ajamiseen, kuten valkoista työväestöä "maahanmuuttajien invaasiolta" puolustavan ja poliittisen korrektiuden ylivaltaa kritisoivan Roy 'Chubby' Brownin tapaus osoittaa.

Toisaalta vastaavalta pohjalta kaikenlainen komiikka, joka ei eksplisiittisesti arvostele etabloitua järjestystä, vaan tyytyy lähinnä viihdyttämään yleisöään, ylläpitäisi epäsuorasti vallitsevaa systeemiä ja olisi näin ollen "oikeistolaista", kuten vaihtoehtokoomikoksi identifioituva John-Luke Roberts kirjassa lausuu. Tämän tapaista foucault'laiseksikin kuvailemaansa mutta lopulta yhtä intuitiivista näkökulmaa soveltamalla Quirkin onnistuu nostaa esiin erilaisia oikeistolaisuuteen assosioituvia nimiä kuten esimerkiksi valtavirran koomikon, veronkierrostakin syytetyn Jimmy Carrin. Ja vaikka hänen lopputulema onkin hieman valju - kyllä, oikeistolaisiksi miellettäviä koomikoita on löydettävissä ja vastaavasti tarvetta ja kysyntää vastaäänille löytyy - luvun anti on pikemminkin komiikan (epä)poliittisuudesta käydyn (brittiläisen) keskustelun premissien eksplikoimisessa, mikä pohjustaa tulevia lukuja havainnollisesti.

\section{Maku- ja luokka-asioita}

Kolmannessa luvussa Quirk esittelee erilaisia vaihtoehtoisen stand up -komiikan klubeja sekä niistä käytyä keskustelua julkisuudessa ja koomikoiden itsensä keskuudessa. Komiikan piirissä vaihtoehtoisuutta tai kokeellisuutta toteutetaan vastustamalla "kaupallisuutta" sen monissa muodoissa, ennen muuta viihteellisyytenä. Tämä ilmenee esimerkiksi niin, että koomikkoihin kohdistettu vaatimus nauruihin on sulkeistettu: kaiken komiikan ei tarvitse tähdätä vain naurattamiseen, ja koomikoilla on myös kaikki lupa epäonnistua. Tuoreemmista vaihtoehtokoomikoista erityishuomiota osakseen saa muun muassa Chris Coltrane, jonka isännöimällä klubilla esiintyjiä rohkaistaan suorin sanoin unohtamaan stand upin perinteiset suoritusvaatimukset, kuten juuri komiikan, mikäli poliittinen viesti tai taiteellinen näkemys sitä vaatii. Muistanpa myös, että Suomessakin koomikot ovat kuvailleet erilaisia "vaihtoehtoklubeja" tiloina, joissa koomikon vaatimukset naurattaa yleisöään ovat väljemmät. Implisiittinen viesti onkin siinä, että näillä klubeilla taiteellinen vapaus ja luova prosessi menevät kaupallisen voiton edelle.

Koska maku liittyy läheisesti sosiaaliseen luokkaan, komiikkamieltymysten ja huumorintajun analyysi tarjoaa kiinnostavan näkymän myös luokkaidentiteetin neuvottelun erityispiirteisiin komiikkadiskurssien kontekstissa. Intuitiiviseen päättelyymme kuuluu tässä yhteydessä ajatus siitä, että ylempää ja keskiluokkaa edustavat sekä usein korkeammin 
koulutetut ihmiset pitäisivät "korkeammasta" ja älyllisemmästä komiikasta, kun taas työväenluokalle kelpaisi matalamielinen viihde ja hauskuutus. Laadukkaaseen komiikkaan pitäisi ylempien luokkien mukaan näin ollen sisältyä huumorin lisäksi merkitystä, joka voi viitata paitsi poliittiseen viestiin myös muodollisiin kokeiluihin. Yleisön pitää ikään kuin työskennellä humoristisen nautintonsa eteen ja tätä kautta nousta huumorin hierarkiassa palkitsevammille tasoille (s. 92).

Kokeellisen stand upin esitysanalyysien sijaan Quirk keskittyykin jälleen siihen, kuinka kokeellisuutta tai vaihtoehtoisuutta komiikan tapauksessa tulkitaan. Onko kokeellisuus ja stand upin muodolla leikittely vastaliikettä kaupallisen komedian kapealle taidekäsitykselle, vai onko vaihtoehtoinen komiikka päinvastoin elitististä ja luokkatietoista snobbailua, ja sellaisenaan komedian kaikkia syleilevän eetoksen vastaista? Quirkin haastattelemat koomikot kuten Josie Long kiistävät ajatuksen, että komiikalla pyrittäisiin sulkemaan tiettyjä ihmisryhmiä ulos. He puolustavat itse moninaisuuden arvoa sekä yksinkertaisesti laatua: intohimolla ja sydämellä tehty komiikka löytää kyllä yleisönsä. Koomikot tiedostavat myös sen, että ihmisten maku jakautuu lukemattomiin sektoreihin ja erilaiset koomikot palvelevat erilaista kysyntää ja makua (s. 97). Stand up -komiikan katkeransuloiseen ironiaan kuuluu nimittäin se, että mikäli koomikko etsii alinta yhteistä nimittäjää, hän tuskin puhuttelee ketään kovin syvällisesti.

\section{Samastumisen politiikka}

Teoksen anti syvenee paitsi kolmannessa makua ja luokkaa koskevassa luvussa, myös päätösluvussa, jossa kirjoittaja pääsee pohtimaan tämän päivän poliittisen kulttuurin ja stand up -komiikan artikulaatioita niin sanotun postanarkismin viitekehyksessä. Hän viittaa postanarkismilla politiikan tutkimuksen juonteeseen, jonka mukaan poliittisessa identifikaatiossa on siirrytty perinteisestä puoluepoliittisesta samastumisesta (jossa eri puolueet ovat tarjonneet kokonaisvaltaisempia viitekehyksiä) kohti spesifimmin, esimerkiksi eläinten oikeuksiin, ympäristöön tai identiteettiin kytkeytyvää ja yksilöllisemmin räätälöityä identifikaatiota. Tätä uutta identiteettipolitiikkaa hallitsevat ennen kaikkea moraaliin ja maailmankuvaan liittyvät arvot: sen piirissä poliittisuus on liudentunut koskemaan myös arkielämän valintoja ja muita aiemmin lähinnä "kulttuurisiksi" (ja "yhteiskunnallisen" rinnalla näin vähempiarvoisiksi) koettuja seikkoja. Puhuessaan vetävästi ja kriittisesti nimenomaan arkisen elämän kokemuksistaan - lajissa, joka nojaa suuressa määrin samastuttavuudelle ja jaettuudelle (ks. Lindfors 2019) - stand up -koomikot ovat kuin vahingossa nousseet juuri tämäntapaisen poliittisuuden keskiöön.

Quirkin mukaan vaihtoehtokoomikot ovatkin julkisina puhujina ja vaikuttajina sisäistäneet erityisen hyvin modernin valtaanalyyttisen ajatuksen hajautuneesta ja arkisesta vallasta. He ymmärtävät sen, miten vallankäyttöä harjoittavat kaikki - eivät vain hallinnolliset auktoriteetit tai muut institutionaaliset tahot - kuten myös sen, että sosiaaliset etuoikeudet edesauttavat sen harjoittamisessa (s. 123). Myös luokkatietoisuus on saanut uusia sävyjä. Siinä missä alkuperäiset vaihtoehtokoomikot saattoivat julistaen alleviivata omaa työläistaustaansa tai vaihtoehtoisesti peitellä keskiluokkaisia juuriaan, nykypäivän koomikot kuten edellä mainittu Josie Long tuovat omat taustansa ja mahdolliset etuoikeutensa - esimerkiksi valkoisuutensa, keskiluokkaisuutensa, yliopistokoulutuksensa - avoimemmin esiin ja pyrkivät hyödyntämään niitä taktisesti yhteisen asian eduksi (s. 110-111). Poliittisen todellisuuden reunaehdot ja toimintaperiaatteet ovat hajanaisempia ja pirstaleisempia kuin 1980-luvulla, mikä tarkoittaa Quirkin mukaan sitä, että myös stand upin poliittista luonnetta ja ylipäätään poliittisen vaikuttamisen ehtoja on arvioitava uusista, vaihtoehtoisista näkökulmista.

Quirkin teos on ainoalaatuinen ja tarpeellinen esitys brittiläisestä vaihtoehtokomiikan perinteestä. Teos antaa työkaluja ja näkökulmia pohtia stand up -komiikan ajankohtaisuutta ja uutta nousua myös 2000-luvulla. Se on analyyttinen katsaus ennen kaikkea niihin ideologisiin periaatteisiin ja premisseihin, jotka leimaavat hyvin monenlaista vaihtoehtoista, poliittista ja niin sanottua kantaa ottavaa komiikkaa Britanniassa ja sen ulkopuolella. Vaikka sen kohde ja esimerkit nousevat Britannian monia muita 
maita rikkaammasta ja monipuolisemmasta komiikan traditiosta, monet kirjan ja kirjassa lainattujen koomikoiden avaamat teemat ovat helposti siirrettävissä ja uudelleentulkittavissa myös muiden (länsi)maiden stand up -komiikan tarkasteluun. Kirjan voisi kuvitella antavan syventäviä virikkeitä myös koomikkojen omille näkemyksille ja keskusteluille esityslajistaan.

\section{Antti Lindfors}

FT, folkloristiikka, Turun yliopisto

\section{Lähteet}

Lindfors, Antti 2019. Intimately Allegorical: The Poetics of Self-Mediation in Stand-Up Comedy. Doctoral dissertation. Turku: Turun yliopisto. Saatavilla: <https://www.utupub. fi/handle/10024/147073> (linkki tarkistettu 24.9.2019).

Lindström, Jukka 2017. Vieraana Atte Järvinen. Noin viikon radio. Me Areena. Saatavilla: <https://areena.yle.fi/ audio/1-4303190> (linkki tarkistettu 14.10.2019). 